\title{
Hairy cell leukemia presenting with progressive pericarditis and pleuritis
}

\author{
Atsushi Iwashige $^{1,2} \cdot$ Makoto Hirosawa $^{1} \cdot$ Junichi Tsukada ${ }^{1}$ \\ Received: 23 April 2018 / Accepted: 21 May 2018 / Published online: 30 May 2018 \\ (C) The Author(s) 2018
}

Dear Editor,

Hairy cell leukemia (HCL) has been recognized as an indolent B cell leukemia characterized by splenomegaly, pancytopenia, and neoplastic cells morphologically with irregular cytoplasmic hair-like projections on smears [1]. However, body fluid retention, such as ascites and pleural effusion, are extremely rare in HCL [2-4].

A 43-year-old Japanese female was referred to our hospital because of a 2-month history of fever and general fatigue. She had suffered from appetite loss and abdominal fullness for 2 years before admission. Physical examination revealed anemia and palpable spleen. Lymph nodes were not palpable. Blood examination showed leukocyte count of $3.5 \times 10^{9} / \mathrm{L}$ with $81 \%$ atypical lymphocytes. Soluble IL-2 receptor was $43,974 \mathrm{U} / \mathrm{mL}$. The atypical lymphocytes were medium-sized with hair-like cytoplasmic projections and were positive for CD19, CD20, CD22, CD11c, CD25, FMC7, and CD103. Images obtained from phase contrast microscopy and transmission electron microscopy (Fig. 1a) also showed hairy cytoplasmic projections along the cellular border. The fried-egg appearance with diffuse infiltration of atypical cells was observed on bone marrow biopsy.

Inflammatory conditions have continued with high fever and serum C-reactive protein levels around $20 \mathrm{mg} / \mathrm{dL}$. Chest $\mathrm{X}$-ray showed pleural effusion and cardiomegaly (Fig. 1b). Echocardiography exhibited pericardial effusion (Fig. 1c). Since dyspnea and hypotension were observed on day 8 after admission, the pericardial and pleural effusions were drained. The effusions were exudative with cell infiltration consisting of atypical lymphocytes (Fig. 1d) and neutrophils. Atypical lymphocytes in the effusions were also positive for CD19,

Junichi Tsukada

jtsukada@med.uoeh-u.ac.jp

1 Hematology, University of Occupational and Environmental Health, 1-1 Iseigaoka, Yahatanishi, Kitakyushu 807-8556, Japan

2 Palliative Care Center, University of Occupational and Environmental Health, Kitakyushu, Japan
CD20, CD22, CD11c, CD25, FMC7, and CD103. Extensive laboratory testing for autoimmune diseases, bacteria, virus, fungus, and tubercle bacillus were all negative.

IL-6 production has been demonstrated in HCL leukemic cells $[5,6]$. In our reverse transcription-polymerase chain reaction analysis, her effusion HCL cells but not her peripheral blood HCL cells showed significant expression of IL-6 mRNA. A remarkably high level of IL-6 (2900 pg/mL) was also observed in the pericardial effusion, compared with that in serum $(5.42 \mathrm{pg} / \mathrm{mL})$. G-CSF levels were elevated in both serum $(318 \mathrm{pg} / \mathrm{mL})$ and the effusion $(2530 \mathrm{pg} / \mathrm{mL})$. Neither $\mathrm{TNF} \alpha$ nor GM-CSF was elevated. Methylprednisolone administration improved her inflammatory conditions such as fever. The pericardial and pleural effusions were significantly decreased after the first cycle of pentostatin $\left(5 \mathrm{mg} / \mathrm{m}^{2}\right)$. However, after the first cycle, pentostatin was discontinued due to skin rash in her trunk and extremities, which were suspected to be caused by pentostatin. Therefore, she was treated with cladribine $(0.09 \mathrm{mg} / \mathrm{kg}$ for 7 days $)$, which completely resolved both pleuritis and pericarditis. There has been no recurrence of pleuropericarditis as well as HCL for 5 years.

To our knowledge, this is the first report of HCL presenting with progressive pericarditis. Early recognition and intervention prolong survival in patients with malignant pericardial effusion, especially in those with chemotherapy-sensitive malignancies such as lymphoma. In our case, an initial relief of the symptoms was obtained by effusion drainage. Further improvement was achieved with systemic chemotherapy. Elevated concentrations of IL-6 have been shown in pericardial effusion associated with hematological malignancies [7-9]. In our case, an extremely high IL-6 concentration was observed in the pericardial effusion. IL-6 mRNA expression was detected only in the effusion HCL cells, suggesting that effusion IL-6 might be involved in the fluid retention and systemic inflammatory responses.

Because the patient has died of breast cancer brain metastasis and her kin are not traceable, the ethics committee of our institute has approved publication of this report. 
Fig. 1 Transmission electron microscopy demonstrated hairy cytoplasmic projections along the cellular border of peripheral blood atypical lymphoid cells (a). Chest X-ray showed pleural effusion and cardiomegaly (b).

Echocardiography examination exhibited pericardial effusion (c). Atypical lymphocytes with hairy cytoplasmic projections were observed in the pericardial effusion (d) Wright-Giemsa staining $\times$ 400)
A

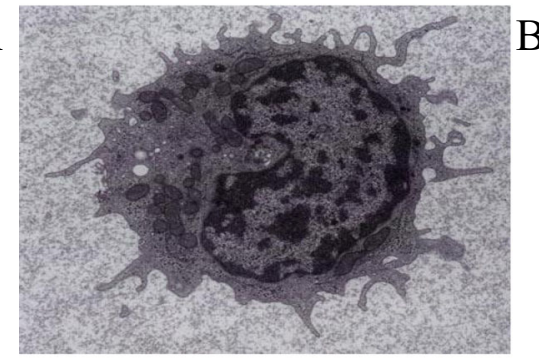

B

C

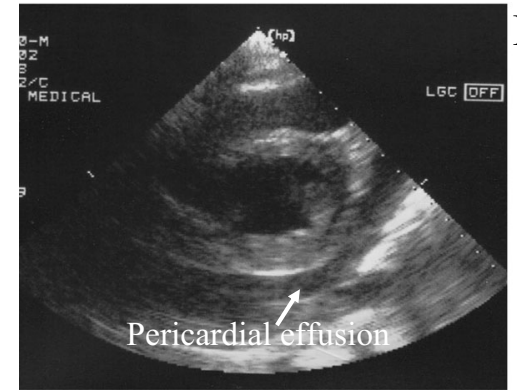

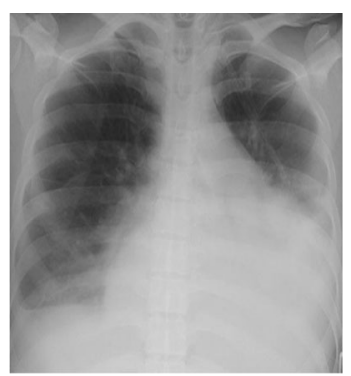

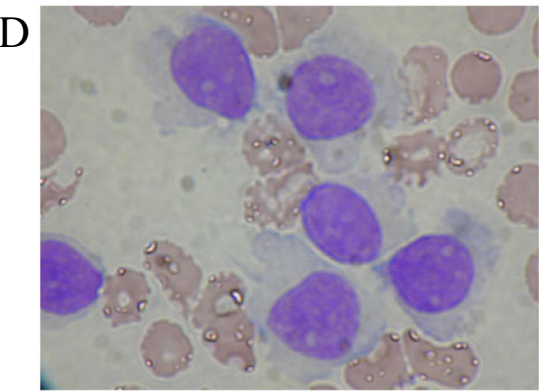

\section{Compliance with ethical standards}

\section{Conflict of interest}

The authors declare that they have no conflict of interest.

Open Access This article is distributed under the terms of the Creative Commons Attribution 4.0 International License (http:// creativecommons.org/licenses/by/4.0/), which permits unrestricted use, distribution, and reproduction in any medium, provided you give appropriate credit to the original author(s) and the source, provide a link to the Creative Commons license, and indicate if changes were made.

\section{References}

1. Bouroncle BA, Wiseman BK, Doan CA (1958) Leukemic reticuloendotheliosis. Blood 13(7):609-630

2. Bouroncle BA (1979) Leukemic reticuloendotheliosis (hairy cell leukemia). Blood 53(3):412-436

3. Bouroncle BA (1987) Unusual presentations and complications of hairy cell leukemia. Leukemia 1(4):288-293
4. Tadmor T, Polliack A (2015) Hairy cell leukemia: uncommon clinical features, unusual sites of involvement and some rare associations. Best Pract Res Clin Haematol 28(4):193-199. https://doi.org/ 10.1016/j.beha.2015.10.020

5. Barut B, Chauhan D, Uchiyama H, Anderson KC (1993) Interleukin6 functions as an intracellular growth factor in hairy cell leukemia in vitro. J Clin Invest 92(5):2346-2352

6. Heslop HE, Bianchi AC, Cordingley FT, Turner M, Chandima W, De Mel CP, Hoffbrand AV, Brenner MK (1990) Effects of interferon alpha on autocrine growth factor loops in B lymphoproliferative disorders. J Exp Med 172(6):1729-1734

7. Takahashi R, Ashihara E, Hirata T, Okawa K, Oku N, Goto H, Inaba T, Fujita N, Shimazaki C, Nakagawa M (1994) Aggressive myeloma with subcutaneous tumor and pericardial involvement. Rinsho Ketsueki 35(3):291-295

8. Pankuweit S, Wadlich A, Meyer E, Portig I, Hufnagel G, Maisch B (2000) Cytokine activation in pericardial fluids in different forms of pericarditis. Herz 25(8):748-754

9. Ristic AD, Pankuweit S, Maksimovic R, Moosdorf R, Maisch B (2013) Pericardial cytokines in neoplastic, autoreactive, and viral pericarditis. Heart Fail Rev 18(3):345-353. https://doi.org/10.1007/ s10741-012-9334-y 